\title{
ANALISIS METAFORA DALAM LAGU JEPANG BERTEMAKAN BUNUH DIRI
}

\author{
R. Pambudi ${ }^{1}$, A. Fadhila ${ }^{2}$, H.S. Kautsar ${ }^{3}$, M.A. Syaifuddin ${ }^{4}$ \\ ${ }^{1234}$ Jurusan Bahasa dan Kebudayaan Jepang, Universitas Diponegoro, Semarang, Jawa Tengah \\ e-mail: rilopambudi275@gmail.com, alvinfadhila28@gmail.com, haqi739@gmail.com, \\ arifsyaifuddin001@gmail.com
}

\begin{abstract}
Abstrak
Artikel ini membahas mengenai metafora dalam lagu-lagu Jepang yang bertemakan bunuh diri. Penelitian menggunakan teori Stephen Ullmann. Penelitian menggunakan data berupa 8 lagu Jepang, yaitu Nautilus oleh Yorushika, Yoru ni Kakeru oleh YOASOBI, Inochi ni Kirawareteiru oleh Kanzaki lori, Ruru-chan no Jisatsu Haishin oleh Shinsei Kamattechan, Kuyamu to Kaite Mirai dan Umareta Imi Nado Nakatta oleh Mafumafu, Aka Pen Onegaishimasu oleh PowaPowaP, dan Ikite Itandayona oleh Aimyon. Metode pengumpulan data menggunakan metode simak dengan teknik lanjutan simak bebas libat cakap (SBLC). Kemudian teknik analisis data menggunakan metode deskriptif. Tujuan dari penelitian ini adalah mengetahui makna metafora apa saja yang digunakan oleh penulis lagu dalam liriknya. Hasil penelitian yang dilakukan pada 8 lagu ditemukan sebanyak 27 data metafora. Dari 27 data tersebut, metafora pengabstrakan paling banyak ditemukan dengan jumlah 16 data, diikuti dengan metafora antropomorfik dengan jumlah 5 data. Metafora pengabstrakan dan metafora sinestetik masing-masing memiliki 4 data dan 2 data.
\end{abstract}

Kata Kunci : Metafora, Lagu Jepang, Bunuh Diri

\begin{abstract}
This article aims to examine the metaphor that is used in suicidal-themed Japanese songs. This article uses the theory by Stephen Ullman. The data used in this article are from Japanese songs, that is Nautilus by Yorushika, Yoru ni Kakeru by YOASOBI, Inochi ni Kirawareteiru by Kanzaki lori, Ruru-chan no Jisatsu Haishin by Shinsei Kamattechan, Kuyamu to Kaite Mirai and Umareta Imi Nado Nakatta by Mafumafu, Aka Pen Onegaishimasu by PowaPowaP, and Ikite Itandayona by Aimyon. The data was collected using simak bebas libat cakap (SBLC) method and analyzed using a descriptive method. The purpose of this article is to find out what kind of metaphors are used by songwriters in their lyrics. The results of research conducted on 8 songs found as many as 27 metaphorical data. Out of the 27 data, abstraction metaphors were mostly found with a total of 16 data, followed by anthropomorphic metaphors with a total of 5 data. Abstraction metaphor and synthetic metaphor have 4 data and 2 data respectively.
\end{abstract}

Keywords: Metaphor, Japanese songs, Suicide

\section{Pendahuluan}

Bunuh diri merupakan hal yang sudah tidak asing di masyarakat Jepang. Jepang merupakan salah satu negara maju dengan angka bunuh diri tertinggi dan diperkirakan terdapat 16 kasus bunuh diri di setiap 100.000 penduduk. Bunuh diri sudah terdapat pada budaya Jepang dari zaman dahulu. Seppuku dan harakiri merupakan contoh bunuh diri yang dilakukan samurai untuk menjaga kehormatannya.

Pada saat ini, angka bunuh diri di Jepang masih tinggi terutama di kalangan anak muda. Penyebab bunuh diri umumnya karena depresi seperti tuntutan kehidupan yang tinggi. Dengan perkembangan teknologi, tingkat depresi juga semakin tinggi disebabkan oleh cyberbullying yang berujung bunuh diri bagi korbannya.

Dengan fenomena bunuh diri yang terdapat di Jepang, penyanyi-penyanyi mulai mengangkat tema ini dalam lagunya. Walaupun lagu-lagu tersebut bertemakan bunuh diri, namun dikemas dengan musik yang ceria sehingga seringkali pendengar yang tidak memahami bahasa Jepang menikmati lagu tersebut tanpa tahu isinya.

Lirik lagu merupakan karya sastra yang berisikan curahan perasaan pribadi atau ide dari pengarangnya. Lirik lagu pada hakikatnya adalah puisi. Seperti halnya puisi, lirik lagu 
juga memiliki unsur yang bisa menimbulkan perasaan estetis, yaitu bahasa. Gaya bahasa yang indah dibutuhkan agar bisa mencapai nilai estetis itu.

Majas atau gaya bahasa adalah cara penyampaian pikiran melalui bahasa yang menggunakan kata-kata kiasan. Makna dari sebuah kalimat yang disampaikan menggunakan majas dapat memberi kesan yang mendalam. Menurut Keraf (2010: 113), majas yang baik harus memiliki unsur kejujuran, sopan-santun, dan menarik. Majas paling sering ditemukan di dalam karya sastra puisi maupun prosa.

Dari sekian banyaknya gaya bahasa yang ada, metafora adalah gaya bahasa yang paling sering digunakan. Metafora memiliki arti ungkapan kebahasaan yang tidak dapat diartikan secara langsung dari lambang yang dipakai, melainkan dari produksi yang dapat dipakai baik oleh lambang maupun dari makna yang dimaksudkan oleh ungkapan bahasa itu (Wahab, 1986: 88-89). Metafora dapat menambahkan efek dramatis pada kalimat dengan memberikan perbandingan yang kontras. Menurut Stephen Ullmann (1962: 213-214) metafora dapat dibagi menjadi empat, yaitu:

1. Metafora antropomorfik merupakan perpindahan nilai, makna dan nafsu yang dimiliki manusia kepada benda mati. Benda mati tersebut tidak bernyawa namun dipahami sebagai hidup atau bernyawa. Metafora ini juga dikenal dengan gaya personifikasi. Contohnya adalah "rumput yang bergoyang", rumput merupakan benda mati, namun dicitrakan hidup dengan bergoyang yang hanya bisa dilakukan makhluk hidup.

2. Metafora kehewanan merupakan penggunaan hewan atau bagian tubuhnya untuk mencitrakan sesuatu yang lain. Metafora ini biasanya didasarkan pada kemiripan yang cukup jelas pada bentuknya. Contohnya "telur mata sapi" karena bentuk kuning bundar yang menyerupai mata sapi.

3. Metafora pengabstrakan merupakan jenis metafora yang dapat dinyatakan sebagai hal yang abstrak atau samar diperlakukan sebagai sesuatu yang konkret atau nyata. Contohnya "bintang lapangan" bintang merupakan sesuatu yang abstrak kemudian diperlakukan sebagai sesuatu yang konkret yaitu pemain andalan.

4. Metafora sinestetik merupakan suatu pemindahan atau pengalihan dari pengalaman yang satu ke pengalaman yang lain, atau dari tanggapan yang satu ke tanggapan yang lain. Contohnya "pahit getirnya kehidupan" pahit merupakan sesuatu yang seharusnya dirasakan oleh lidah namun diibaratkan dalam kehidupan karena pahit adalah rasa yang tidak enak.

Penelitian ini akan menggunakan 8 lagu yang berjudul Nautilus oleh Yorushika, Ruruchan no Jisatsu Haishin oleh Shinsei Kamattechan, Yoru ni Kakeru oleh YOASOBI, Inochi ni Kirawareteiru oleh Kanzaki lori, Kuyamu to Kaite Mirai oleh Mafumafu, Ikite Itandayona oleh Aimyon, Aka Pen Onegaishimasu oleh PowaPowaP dan Umareta Imi Nado Nakatta oleh Mafumafu. Lagu-lagu tersebut dipilih karena walaupun sama-sama bertemakan tentang bunuh diri, setiap lagu memiliki keunikan tersendiri berupa penggunaan metafora yang membedakan dari lainnya. Oleh karena itu penulis tertarik untuk melakukan penelitian mengenai makna metafora yang terdapat pada lagu-lagu tersebut.

\section{Metode}

Metode pengumpulan data yang digunakan yaitu metode simak dengan teknik lanjutan simak bebas libat cakap karena data diperoleh tanpa berpartisipasi dalam pembicaraan. Metode simak digunakan dengan menyimak lirik lagu yang dipilih dan mencari metafora yang ada. Teknik catat juga digunakan bersamaan saat menyimak lirik lagu untuk memudahkan dalam melakukan penelitian.

Metode analisis data yang digunakan adalah metode deskriptif yaitu dengan menggambarkan metafora yang terdapat pada lirik lagu Nautilus oleh Yorushika, Ruru-chan no Jisatsu Haishin oleh Shinsei Kamattechan, Yoru ni Kakeru oleh YOASOBI, Inochi ni Kirawareteiru oleh Kanzaki lori, Kuyamu to Kaite Mirai oleh Mafumafu, Ikite Itandayona oleh Aimyon, Aka Pen Onegaishimasu oleh PowaPowaP dan Umareta Imi Nado Nakatta oleh Mafumafu. 


\section{Hasil dan Pembahasan Metafora Antropomorfik}

Berikut ini merupakan data metafora antropomorfik

1. 夏草が邪魔をする Natsu kusa ga jama wo suru Rerumputan musim panas mengganggu

(Nautilus - Yorushika)

Jenis metafora ini adalah metafora antropomorfik karena dalam lirik tersebut penyair mengibaratkan rerumputan musim panas sebagai pengganggu, padahal sifat pengganggu hanya dimiliki oleh manusia. Lirik tersebut memiliki makna terganggu karena keadaan kota yang ramai saat musim panas.

\section{2. 夕暮れは時々優しく}

Yuugure wa tokidoki yasashiku

Senja terkadang lembut

(Ruru-chan no Jisatsu Haishin - Shinsei Kamattechan)

Pada lirik di atas, ditemukan metafora antropomorfik. Sesuai dengan definisinya, pada lirik tersebut, metafora ditemukan pada kata yasashiku. Kata yasashiku merupakan kata sifat berbentuk (i)keyoshi yaitu baik atau lembut yang biasanya dilakukan oleh manusia, akan tetapi dalam lirik tersebut yang lembut merupakan senja. Makna yang terkandung dalam lirik diatas adalah cuaca senja yang terkadang cerah membuat tokoh aku merasa ditemani dan tidak merasa kesepian.

3. 不条理な御託で刺してくれたら

Fujourina gotaku de sashite kuretara

Jika kamu menusukku dengan argumen absurdmu

(Kuyamu to Kaite Mirai - Mafumafu)

Pada data diatas, metafora antropomorfik ditemukan pada kalimat Gotaku de Sashite. Kata Gotaku merupakan kata benda yang memiliki makna 'absurd' dan kata Sashite merupakan kata kerja yang memiliki makna 'menusuk'. Kalimat Gotaku de Sashite menunjukkan seolah-olah sebuah kata argumen dapat 'menusuk' seseorang. Kata menusuk biasanya digunakan untuk kalimat seperti 'menusuk menggunakan pisau'.

4. 塞いだ過去に咲いた世界

Fusaida kako ni saita sekai

Dunia yang mekar di masa lalu yang terhalang

(Kuyamu to Kaite Mirai - Mafumafu)

Pada data diatas, metafora antromorfik ditemukan pada kalimat Saita sekai. Kata Saita merupakan kata kerja bentuk lampau yang telah mengalami perubahan dari bentuk awalnya yaitu Saku yang memiliki makna 'mekar'. Kata Sekai merupakan kata benda yang memiliki makna 'dunia'. Kalimat Saita sekai menunjukkan seolah dunia mekar seperti bunga.

5. 生きた証の赤い血は

Ikita akashi no akai chi wa

Darah merah bukti hidup

(Ikite Itandayona - Aimyon) 
Jenis metafora ini adalah metafora antropomorfik karena dalam lirik tersebut penyair mengibaratkan darah bisa hidup, padahal sifat hidup hanya dimiliki oleh makhluk hidup sedangkan darah adalah benda mati. Lirik tersebut memiliki makna darah menjadi bukti terjadinya bunuh diri.

\section{Metafora Kehewanan}

Berikut ini merupakan data metafora kehewanan

1. 野良猫とワルツを踊った

Noraneko to warutsu wo odotta

Aku berdansa dengan kucing liar

(Ruru-chan no Jisatsu Haishin - Shinsei Kamattechan)

Pada lirik diatas ditemukan metafora kehewanan. Metafora kehewanan adalah metafora yang menggunakan binatang, bagian tubuh binatang, atau sesuatu yang berkaitan dengan binatang untuk pencitraan sesuatu yang lain. Metafora kehewanan dalam kutipan lirik ditunjukkan pada kata noraneko yang memiliki arti kucing liar. Sehingga pada metafora ini termasuk ke dalam metafora kehewanan. Noraneko atau kucing liar adalah adalah kucing yang tidak memiliki tuan dan memiliki kehidupan bebas. Makna noraneko disini identik dengan simbol kehidupan yang bebas dan tidak ada yang mengatur.

Jenis metafora ini adalah metafora kehewanan. Dalam lirik ini seseorang dipadankan dengan hewan. Makna dalam lirik tersebut adalah penyair menggambarkan tokoh aku yang melakukan pergaulan bebas.

2. 飛び交うデータの中で

Tobikau deeta no naka de

Di tengah tengah data yang berterbangan

(Ruru-chan no Jisatsu Haishin - Shinsei Kamattechan)

Jenis metafora ini adalah metafora kehewanan. Dalam lirik ini penyair menggunakan kata tobikau terbang yang identik dengan jenis burung. Lirik dalam lagu tersebut memiliki makna tokoh aku yang selalu dikelilingi oleh orang orang di internet karena dia melakukan streaming.

\section{3. ネコと話せる魔女さ}

Neko to hanaseru majo sa

Aku akan menjadi penyihir yang berbicara dengan kucing

(Ruru-chan no Jisatsu Haishin - Shinsei Kamattechan)

Lirik tersebut terdapat metafora kehewanan. Metafora kehewanan ada pada kata neko yang berarti kucing. Dalam lirik ini penyair menyebutkan tokoh aku berbicara dengan kucing yang diartikan sebagai pengguna internet.

\section{4. そんな言葉が飛び交う中で \\ Sonna kotoba ga tobikau naka de \\ Dengan kata-kata seperti itu terbang di sekitar.}

(Ikite Itandayona - Aimyon)

Jenis metafora ini adalah metafora kehewanan. Dalam lirik ini penyair menggunakan kata tobikau terbang yang identik dengan jenis burung. Lirik dalam lagu tersebut memiliki makna kata-kata yang keluar dari orang orang seakan akan terbang karena terus keluar tanpa berhenti. 


\section{Metafora Pengabstrakan}

Berikut ini merupakan data metafora pengabstrakan

1. 靴を捨てたんだっけ

裸足のままなんて度胸もある訳がないや

Kutsu wo sutetan dakke

Hadashi no mama nante dokyou mo aru wake ga nai ya

Apa aku membuang sepatuku?

Aku takkan berani jika pergi dengan bertelanjang kaki

(Nautilus - Yorushika)

Jenis metafora adalah metafora pengabstrakan. Metafora pengabstrakan merupakan hal-hal yang abstrak diperlakukan sebagai sesuatu yang bernyawa sehingga dapat berbuat nyata atau hidup. Pada lirik di atas, metafora terdapat pada kata sutetan dan hadashi. Dalam lirik di atas, kekasih tokoh aku bertanya apakah harus membuang sepatunya dalam hal ini merupakan kehidupannya. Lirik tersebut menceritakan kekasih dari tokoh aku sudah tidak sanggup menjalani hidup dan berkomitmen untuk membuangnya (bunuh diri). Metafora kedua adalah hadashi yang secara harfiah adalah telanjang kaki. Dalam lirik ini, makna yang terkandung dari hadashi adalah mati. Makna dari lirik tersebut adalah kekasih dari tokoh aku masih ragu ragu apakah dia memiliki keberanian untuk bunuh diri dan siap untuk mati.

2. このままの速さで今日を泳いで

Kono mama no hayasa de kyou wo oyoide

Aku mengarungi hari ini dengan kecepatan biasanya

(Nautilus - Yorushika)

Pada lirik di atas ditemukan metafora pengabstrakan pada kata oyoide. Kata oyoide merupakan kata kerja bentuk te dari oyogu yang artinya berenang, biasanya terjadi saat orang pergi ke kolam renang, laut dan sebagainya. oyogu berenang adalah gerakan berpindah tempat secara teratur di air dengan cepat menggunakan tangan dan kaki. Makna dari lirik tersebut menggambarkan tokoh aku ingin menjalani kehidupan sehari harinya layaknya air yang tenang.

3. 沈むのように溶けてゆくように

Shizumu no you ni tokete yuku you ini

Aku merasa akan tenggelam, aku merasa akan meleleh

(Yoru ni Kakeru - YOASOBI)

Pada lirik diatas ditemukan metafora pengabstrakan. Metafora terdapat pada kata Tokete. Kata Tokete merupakan kata yang tergolong dalam kelas kata verba. Kata Tokete pada data diatas merupakan kata yang telah mengalami perubahan dari bentuk awal kata Tokeru. Kata Tokete memiliki makna 'meleleh'. Meleleh biasanya digunakan untuk benda yang dapat berubah bentuk dari padat menjadi cair. Pada data diatas, kata Tokete digunakan pada tokoh 'Aku' yang merupakan manusia.

4. 軽々しく命を見てる

Karugarushiku inochi wo miteru

Dan melihat kehidupan kita dengan sepele

(Inochi ni Kirawareteiru - Kanzaki lori)

Pada data tersebut, metafora pengabstrakan terdapat dalam kata miteru. Inochi atau kehidupan merupakan sesuatu yang abstrak, namun dalam lirik tersebut diperlakukan sebagai sesuatu yang dapat dilihat, yaitu miteru yang artinya melihat. Lirik lagu tersebut termasuk ke dalam jenis metafora pengabstrakan karena penyair menggambarkan nyawa, 
hal yang abstrak, menjadi sesuatu yang dapat dilihat. Lirik tersebut memiliki makna bahwa kita menganggap kehidupan sebagai sesuatu yang tidak terlalu penting.

5. 価值観もエゴも押し付けて Kachikan mo ego mo oshitsukete

Selalu mendorong nilai-nilai dan ego

(Inochi ni Kirawareteiru - Kanzaki lori)

Makna metafora terdapat pada kata oshitsukete. Oshitsukete adalah kata kerja majemuk bentuk te dari kata osu yang berarti mendorong dari tsukeru yang berarti menambahkan. Nilai-nilai dan ego adalah sesuatu yang abstrak namun di sini dianggap sebagai hal yang jelas; dapat didorong. Lirik di atas memiliki makna kita telah dibenci oleh dunia ini karena orang di sekitar kita sering sekali memaksakan nilai-nilai dan ego mereka ke kita sehingga membuat diri kita sering depresi karena memikirkannya.

6. 矛盾を抱えて生きてくなんて Mujun wo kakaete ikiteku nante

Hidup sambil memeluk sebuah kontradiksi

(Inochi ni Kirawareteiru - Kanzaki lori)

Pada lirik di atas ditemukan metafora pengabstrakan. Pada lirik tersebut, metafora terdapat dalam kata kakaete. Kata kakaete merupakan kata kerja bentuk te dan berasal dari kata kerja kakaeru yang artinya 'memeluk'. Kontradiksi adalah suatu hal yang abstrak dan pada lirik tersebut diperlakukan sebagai sesuatu yang jelas; dapat dipeluk.

7. 街のBluetoothがあたしを壊した Machi no bluetooth ga atashi wo kowashita Kota bluetooth telah menghancurkanku

(Ruru-chan no Jisatsu Haishin - Shinsei Kamattechan)

Pada lirik di atas ditemukan metafora pengabstrakan karena penyair menggambarkan kota bluetooth dapat menghancurkan. Metafora pengabstrakan terdapat dalam kata kowashita. Kota bluetooth merupakan sesuatu yang abstrak, namun dalam lirik tersebut diperlakukan sebagai sesuatu yang dapat menghancurkan. Makna dalam lirik diatas adalah kondisi di sekitar tokoh aku baik keluarga, teman atau sekolah yang tidak supportive membuat mentalnya hancur.

8. UFOに飛び乗って UFO ni tobinotte Aku melompat ke UFO

(Ruru-chan no Jisatsu Haishin - Shinsei Kamattechan)

Metafora pengabstrakan pada data tersebut terdapat pada kata tobinotte. Tobinotte merupakan kata verba majemuk bentuk te dari verba tobu yang artinya 'melompat' dan noru yang artinya 'menaiki'. UFO merupakan sesuatu yang abstrak namun diperlakukan sebagai sesuatu yang dapat dinaiki. Makna dari lirik lagu tersebut adalah tokoh Aku yang sudah depresi dan kesepian di dunia nyata hingga kemudian memutuskan untuk melarikan diri ke dunia maya dengan melakukan siaran langsung.

9. インクを詰め替えたら続きをしようどんな言葉よりも早く早く Inku wo tsumikae tara tsudzuki wo shiyou donna kotoba yorimo hayaku, hayaku Saat aku selesai mengisi tinta, ayo pergi lebih cepat dari kata

(Aka Pen Onegaishimasu - PowaPowaP) 
Jenis metafora diatas adalah metafora pengabstrakan. Pada lirik ini mengisi tinta dalam masyarakat Jepang sering dikaitkan dengan memulai kembali kehidupan. Setelah selesai mengisi tinta atau mengulang kehidupan dia ingin melanjutkannya dengan cepat. Kata sendiri bergerak namun pada lirik ini dikatakan lebih cepat dari kata karena menghubungkan dengan lirik sebelumnya yang berkaitan dengan tinta.

10. 屁理屈少々混ぜたら腕がなるよそんな理論よりも鋭く鋭く Herikutsu shoushou mazetara ude ga naru yo sonna riron yorimo surudoku surudoku

Bila aku mencampur sofisme, aku akan bisa menunjukan kemampuanku lebih tajam dari pada logika

(Aka Pen Onegaishimasu - PowaPowaP)

Jenis metafora diatas adalah metafora pengabstrakan. Sofisme sendiri adalah sikap yang menyatakan kebenaran adalah sesuatu yang relatif. Sikap ini pada awalnya digunakan cendekiawan pada zaman Yunani kuno untuk berpidato mempengaruhi orang banyak. Logika bukanlah benda yang memiliki bentuk tertentu namun dikatakan tajam untuk menunjukan kemampuannya lebih baik daripada logika itu.

11. あの時吐いた嘘に赤いペけをどんな理不尽よりも正しく正しく Ano toki haita uso ni akai peke wo donna rifujin yorimo tadashiku, tadashiku Tanda merah di kebohongan yang aku muntahkan saat itu lebih benar daripada hal irasional itu

(Aka Pen Onegaishimasu - PowaPowaP)

Jenis metafora diatas adalah metafora pengabstrakan. Kebohongan yang dimuntahkan bisa diartikan sebagai kebohongan yang diucapkan saat itu. Kebohongan itu berupa keinginan menjadi orang lain, walaupun disadari itu sebuah kebohongan namun itu lebih benar daripada hal irasional.

12. 煮え切らない毎日に赤いペけをどんなドラマよりも鋭く鋭く Niekeranai mainichi ni akai peke wo donna dorama yorimo surudoku surudoku Tanda merah di keseharian yang tidak pasti ini lebih tajam daripada drama (Aka Pen Onegaishimasu - PowaPowaP)

Jenis metafora diatas adalah metafora pengabstrakan. Pada kehidupan yang serba tidak pasti, selalu muncul kebohongan dan kepalsuan di setiap harinya. Hal ini diungkapkan lebih tajam daripada drama, yaitu jumlah kebohongan dan kepalsuan di kehidupan ini lebih banyak dibanding drama yang isinya sudah banyak dengan kepalsuan.

\section{3. たちまちここらはネットの慨食 \\ Tachimachi kokora wa netto no eijiki \\ Tempat ini pun makanan warga internet}

(Ikite Itandayona - Aimyon)

Pada lirik di atas ditemukan metafora pengabstrakan karena penyair menggambarkan tempat yang tiba tiba menjadi makanan warga internet. Metafora pengabstrakan terdapat dalam kata netto no eijiki. Makanan warga internet merupakan sesuatu yang abstrak, namun dalam lirik tersebut diperlakukan sebagai sesuatu yang menarik perhatian pengguna dunia maya. Makna dalam lirik diatas adalah tempat terjadinya bunuh diri selalu mendapat perhatian warga internet sehingga diibaratkan sebagai makanan. 
14. 立ち入り禁止の黄色いテープ

Tachiiri kinshi no kiiroi teepu

Dibentangkan garis kuning melarang lewat

(Ikite Itandayona - Aimyon)

Jenis metafora diatas adalah metafora pengabstrakan. Metafora ini ditujukan pada kata kiiro teepu yang artinya garis kuning. Pada setiap akhir kasus bunuh diri polisi akan memberi garis kuning untuk melindungi tempat kejadian. Kata garis kuning dalam lirik merujuk pada garis polisi.

15. 厚紙の箱に捨てられた命ならば值打ちはないか?

Atsugami no hako ni suterareta inochi naraba neuchi wa naika?

Bagaimana nilai dari kehidupan jika itu dibuang dalam kotak kardus?

(Umareta Imi Nado Nakatta - Mafumafu)

Dalam lirik ini terdapat metafora pengabstrakan. Metafora dalam lirik ini terdapat pada kata suterareta. Kata suterareta adalah kata kerja bentuk pasif yang berasal dari kata kerja suteru yang berarti "membuang" dan biasanya dikenakan pada benda, namun dalam lirik ini digunakan untuk hal yang abstrak yaitu kehidupan. Makna yang terkandung dalam lirik ini adalah penyair ingin menyampaikan bahwa nyawa miliknya itu ibarat kehidupan yang sudah dibuang dalam "sampah", diperlakukan secara ceroboh.

16. 底知れた愚鈍な世界だ

Sokoshireta gudon na sekai da

Ini adalah dunia yang bodoh dan tak dapat dipahami

(Umareta Imi Nado Nakatta - Mafumafu)

Pada data lirik ini, ditemukan metafora pengabstrakan. Metafora dalam lirik ini terdapat dalam kata gudon. Gudon yang berarti bodoh biasanya ditujukan kepada manusia, namun dalam hal ini ditujukan kepada dunia yang merupakan sesuatu yang abstrak. Lirik dalam lagu tersebut memiliki makna penyair kesulitan untuk memahami isi hati dari orang lain.

\section{Metafora Sinestetik}

Berikut ini merupakan data metafora sinestetik:

1. 喉が渴くとか、心が痛いとか

Nodo ga kawaku toka, kokoro ga itai toka Aku merasa haus dan hatiku terasa sakit

(Nautilus - Yorushika)

Jenis metafora ini adalah sinestetik. Dalam lirik tersebut kata nodo ga kawaku secara harfiah memiliki arti merasa haus. Kata haus secara umum adalah sesuatu yang bisa dirasakan semua manusia, baik itu haus ingin minum atau haus akan hal lainnya. Namun pada bait ini, haus yang dimaksudkan penyair adalah perasaan ingin bertemu setelah sekian lama berpisah.

2. 触れる心無い言葉うるさい声に涙が零れそうでも Fureru kokoro nai kotoba urusai koe ni namida ga koboresou demo Meskipun aku seperti menangis, suara berisik itu tidak dapat menyentuh hatiku

(Yoru ni Kakeru - YOASOBI)

Pada lirik di atas ditemukan metafora sinestetik. Metafora terdapat pada kata Fureru. Kata Fureru. Kata Fureru merupakan kata yang tergolong kedalam kelas bahasa verba. Kata 
Fureru memiliki makna 'menyentuh'. 'Menyentuh' biasanya digunakan pada saat kita 'mengenai sesuatu yang dapat terlihat' oleh indra penglihatan. Pada data diatas, 'Aku' memberlakukan suara; yang merupakan sesuatu yang tidak terlihat; sebagai sesuatu yang dapat terlihat.

\section{Simpulan dan Saran}

Berdasarkan hasil analisis dan penelitian diatas, ditemukan metafora yang tersebar pada 8 lagu. Rincian metafora seperti berikut

\begin{tabular}{|c|c|c|c|c|c|}
\hline Judul Lagu & $\begin{array}{c}\text { Metafora } \\
\text { Antromofik }\end{array}$ & $\begin{array}{c}\text { Metafora } \\
\text { Kehewanan }\end{array}$ & $\begin{array}{c}\text { Metafora } \\
\text { Pengabstrakan }\end{array}$ & $\begin{array}{l}\text { Metaforda } \\
\text { Sinestetik }\end{array}$ & Jumlah \\
\hline $\begin{array}{l}\text { Nautilus - } \\
\text { Yorushika }\end{array}$ & 1 & - & 2 & 1 & 4 \\
\hline $\begin{array}{c}\text { Yori ni Kakeru - } \\
\text { YOASOBI }\end{array}$ & - & - & 1 & 1 & 2 \\
\hline $\begin{array}{c}\text { Inochi ni } \\
\text { Kirawareteitu - } \\
\text { Kanzaki lori }\end{array}$ & - & - & 3 & - & 3 \\
\hline $\begin{array}{c}\text { Ruru-chan no } \\
\text { Jihatsu Haishin } \\
\text { - Shinsei } \\
\text { Kamattechan }\end{array}$ & 1 & 3 & 2 & - & 6 \\
\hline $\begin{array}{l}\text { Kuyamu to } \\
\text { Kaite Mirai - } \\
\text { Mafumafu }\end{array}$ & 2 & - & - & - & 2 \\
\hline $\begin{array}{l}\text { Umareta Imi } \\
\text { Nado Nakatta - } \\
\text { Mafumafu }\end{array}$ & - & - & 2 & - & 2 \\
\hline $\begin{array}{c}\text { Aka Pen } \\
\text { Onegaishimasu } \\
\text { - PowaPowaP }\end{array}$ & - & - & 4 & - & 4 \\
\hline $\begin{array}{c}\text { Ikite } \\
\text { Itandayona - } \\
\text { Aimyon }\end{array}$ & 1 & 1 & 2 & - & 4 \\
\hline Total & 5 & 4 & 16 & 2 & 27 \\
\hline
\end{tabular}

Berdasarkan tabel diatas, metafora pengabstrakan paling banyak ditemukan pada data diatas dengan total 16 data yang tersebar pada 7 lagu. Diikuti dengan metafora antromorfik dengan total 5 data. Metafora kehewanan dan metafora sinestetik memiliki masing-masing total 4 lagu dan 2 lagu.

Data diatas menunjukkan sebagian besar lagu mengaplikasian penggunaan bahasa abstrak pada lirik lagu, seperti panas mengganggu, senja lembut, dll. Tujuannya adalah untuk memperindah bentuk aspek kebahasaan dalam lirik lagu.

Dalam penelitian masih banyak kekurangan yang dilakukan penulis. Penulis berharap penelitian ini dapat membantu memberikan referensi mengenai metafora yang terdapat dalam lagu, khususnya lagu Jepang. Dalam penelitian ini, penulis menggunakan lagu bertemakan bunuh diri, penulis berharap di lain waktu terdapat penelitian lirik lagu dengan tema yang berbeda. 


\section{Daftar Pustaka}

Keraf, G. 2010. Diksi dan Gaya Bahasa. Jakarta: PT Gramedia Pustaka Utama.

Knowles, M. \& Rosamund, M. 2006. Introducing Metaphor. London and New York: Routledge.

Marthatiana, R., dkk. 2020. Analisis Makna Metafora Dalam Lirik Lagu "Ignite". Jurnal Pendidikan Bahasa Jepang, 6(2), 218-222.

Padmadewi, A.A.A.D., dkk. 2020. Analisis Metafora Dalam Lirik Lagu "First Love Utada Hikaru". Jurnal Pendidikan Bahasa Jepang, 6(2), 283-286

Ullmann, S. 1962. Semantics: An Introduction to the Science of Meaning. Oxford: Basil Blackwell

Wahab, A. 1986. Metafora Sebagai Alat Pelacak Sistem Ekologi dalam PELLBA 3. Penyunting: Bambang Kaswanti Purwo. Yogyakarta: Kanisius

Nisaa, E. A. 2020. Metafora dalam Lagu Jepang Yang Bertemakan Cinta Tahun 2019. Skripsi. Semarang: Universitas Diponegoro 